\title{
SEASONAL VARIATION OF RESIDUAL: FLOW IN THE EAST SEA
}

\author{
Dinh VAN MANH \\ Institute of Mechanics, NCST, VN \\ Tetsuo Yanagi \\ Kyushu University, Japan
}

\begin{abstract}
A diagnostic three-dimensional numerical model has been established in order to reveal the seasonal variation of residual flow, including wind-driven current, densitydriven current and tide-induced residual current, in the East Sea. The observed data on water temperature, salinity (from JODC, 1930-1996) and wind (from COADS, 1961-1991) were exploited in this study. Residual flows in 4 seasons (spring, summer, autumn and winter) were simulated. Furthermore, the contribution of each component, wind-driven, density-driven and tide-induced residual current, was evaluated. On the basis of the obtained results, it is shown that the wind-driven current plays an important role in the basin-wide circulation in the East Sea, especially in the surface layer. At the lower levels, the densitydriven current becomes more significant. The tide-induced residual current is relatively small.
\end{abstract}

\section{Introduction}

The East Sea (ES) is the largest marginal sea in the Southeast Asian Waters. The northern part is a deep-sea basin where depth exceeds $4000 \mathrm{~m}$. The southern part is a shelf sea, where depth ranges between $50 \mathrm{~m}$ and $100 \mathrm{~m}$. The continental slope is steep and there is no continental shelf on the eastside of the basin. Exchange of waters between the ES and the surrounding waters mainly occurs through the Taiwan Strait, Bashi Channel and Karimata Strait (see Fig. 1).

The ES is situated within the monsoon regime, and the major circulation in the basin is driven by the monsoon wind (Wyrtki, 1961). In winter, the northeast wind prevails over the whole region, in summer the wind distribution totally reverses. The most significant ocean circulation in response to the changing wind is the current off the coast of Vietnam. In Wyrtki's surface current charts, a strong southward current develops along the coast of Vietnam during the northeast monsoon and the current becomes northeastward during the southwest monsoon.

Up to now only several numerical simulations have been made in the ES. Pohlmann (1987) calculated the circulation in the ES in January and July on the basis of the three-dimensional model and using climatological stratification and wind forcing. Shaw et al (1994) used a three-dimensional, primitive model with the finer grid in the vertical direction (21 layers) to investigate the seasonal variation of the basinwide circulation driven by monthly varying wind and inflow/outflow through open 


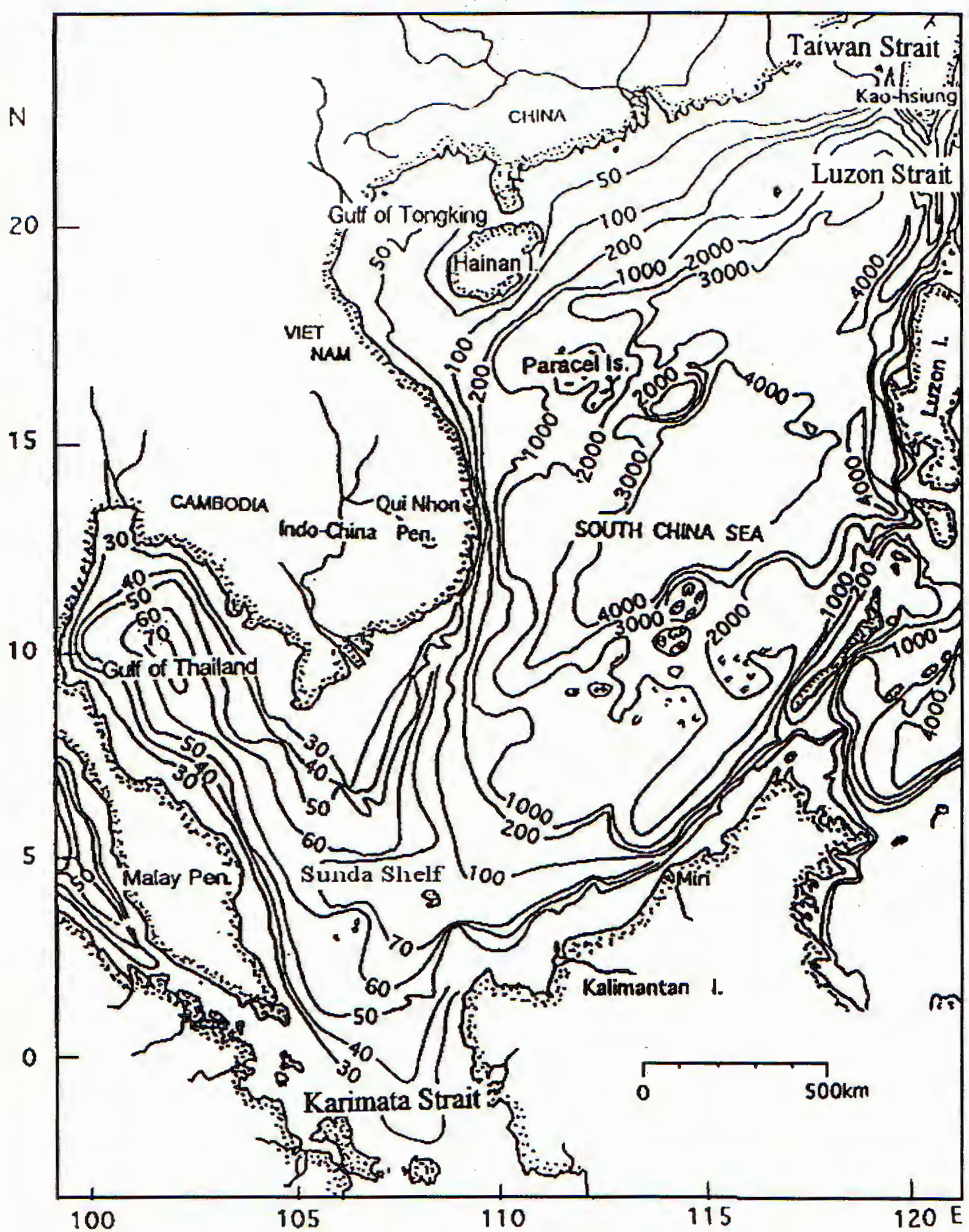

Fig. 1. Location of the East Sea and its topography. Numbers show the depth in meter 
boundaries. Recently, Uu et al (2001) has used a prognostic three-dimensional model for considering monthly patterns of circulation and thermo-saline fields in ES.

In this study, a diagnostic three-dimensional model, using the finite difference method in the sigma coordinates, is employed to investigate the seasonal variation of residual flow, including wind-driven current, density-driven current and tide-induced residual flow, in the ES. By using the newer data set of sea water temperature and salinity as well as using the finer grid sizes, especially in the vertical direction, the seasonal circulations of residual flow for 4 seasons (spring, summer, autumn and winter) are simulated. In comparison with the observed data as well as with some former studies, it can be said that the obtained results have pointed out the major characteristics of seasonal circulation in the ES.

\section{Observed data}

Monthly averaged wind data from 1961 to 1991 were extracted from the Comprehensive Ocean Atmosphere Data Set (COADS) developed by NOAA (National Oceanic and Atmospheric Administration). Next, they were averaged in four seasons: spring (March to May), summer (June to August), autumn (September to November) and winter (December to following February), as shown in Fig. 2. During spring, the $\mathrm{NE}$ monsoon wind still predominates. However, due to developing of SW monsoon wind, the wind direction is northward in the Gulf of Thailand and northwestward in the southwestern part of the Gulf of Tongking. In summer the SW monsoon wind predominates over the whole ES. During autumn, the NE wind develops and prevails in the northern part of the ES. The meeting of NE and SW wind in the west of the Philippines results in that the wind direction is eastward. In winter the NE monsoon wind prevails over the whole region.

Observational data of sea water temperature and salinity at 25 standard levels from surface to $4000 \mathrm{~m}$ deep in the 1930-1996 period were obtained from the Marine Environmental Atlas of Japan Oceanographic Data Center (JODC). The observational locations of sea water temperature and salinity in 4 seasons are shown in Fig. 3.

First, the horizontal distributions of observed water temperature and salinity at each standard level are obtained by using the Kriging method (Cressei, 1991). Then the cubic spline method (Ahlberg, 1967) is applied to get their vertical distributions. During spring, the sea surface water temperature (SST) is more than $29^{\circ} \mathrm{C}$ (high) in the Gulf of Thailand and $24^{\circ} \mathrm{C}$ (low) in the Gulf of Tongking. In summer, generally SST is highest and horizontal temperature gradient is quite small (from $29^{\circ} \mathrm{C}$ in the south to $28^{\circ} \mathrm{C}$ in the north). The highest SST $\left(29.2^{\circ} \mathrm{C}\right)$ occurs in the coastal area of Kalimantan. In autumn, SST is lower in comparison to that in summer. In winter, SST is lowest (less than $21.5^{\circ} \mathrm{C}$ in the coastal zone of China). The sea surface salinity (SSS) does not change very much from season to season. Generally, SSS is highest in spring and lowest in autumn, except in the Gulf of Thailand (highest in 
summer and lowest in winter).

Besides, harmonic constants of 4 major constituents of tidal current $\left(\mathrm{M}_{2}, \mathrm{~S}_{2}, \mathrm{~K}_{1}\right.$ and $\mathrm{O}_{1}$ ) on the basis of numerical tidal model (Manh and Yanagi, 1997) are used to calculate tidal stresses in this numerical model.
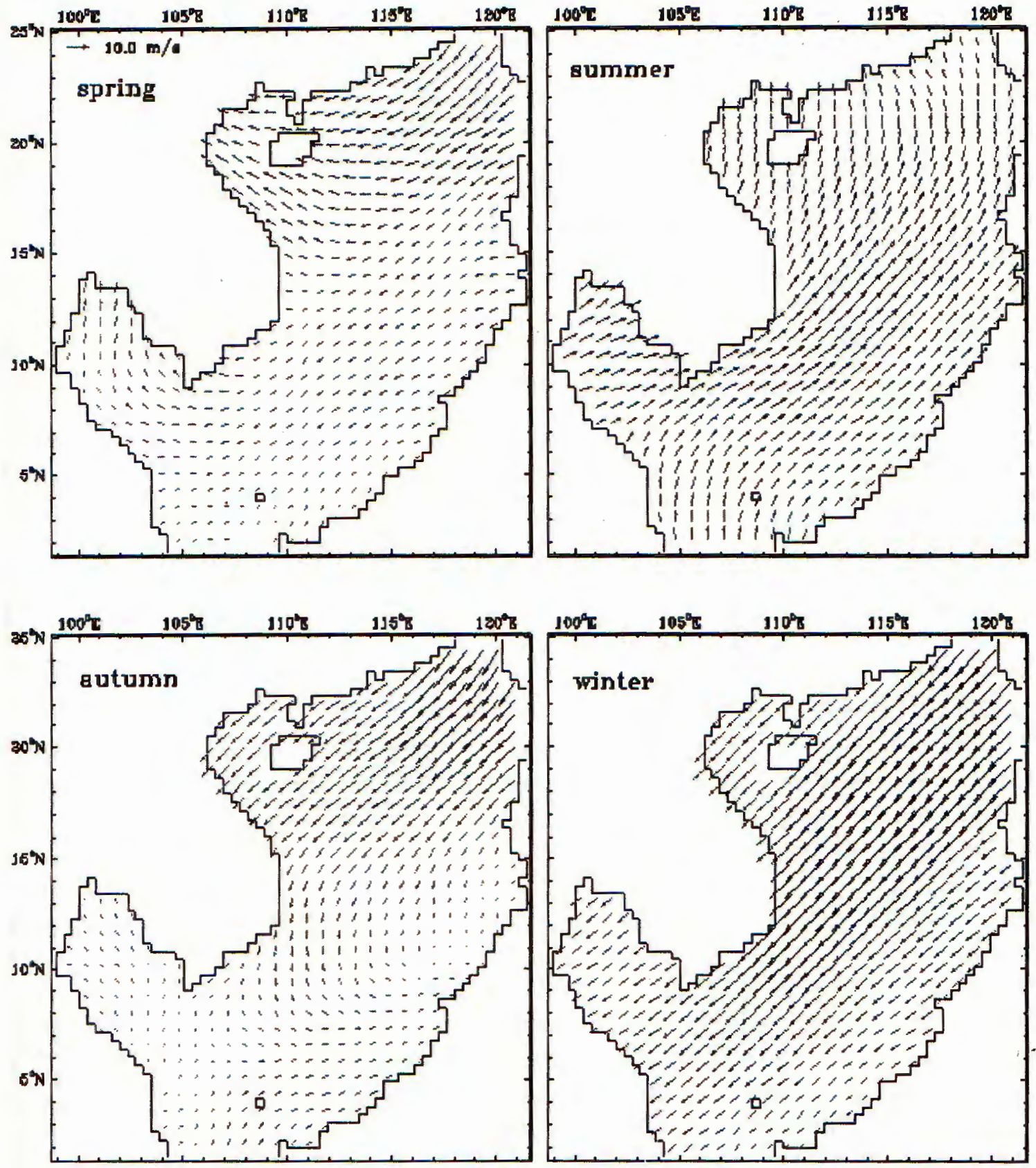

Fig. 2. Average wind fields, extracted from the Ocean Atmosphere Data Set, NOAA, in 4 seasons (spring, simmer, autumn and winter) 

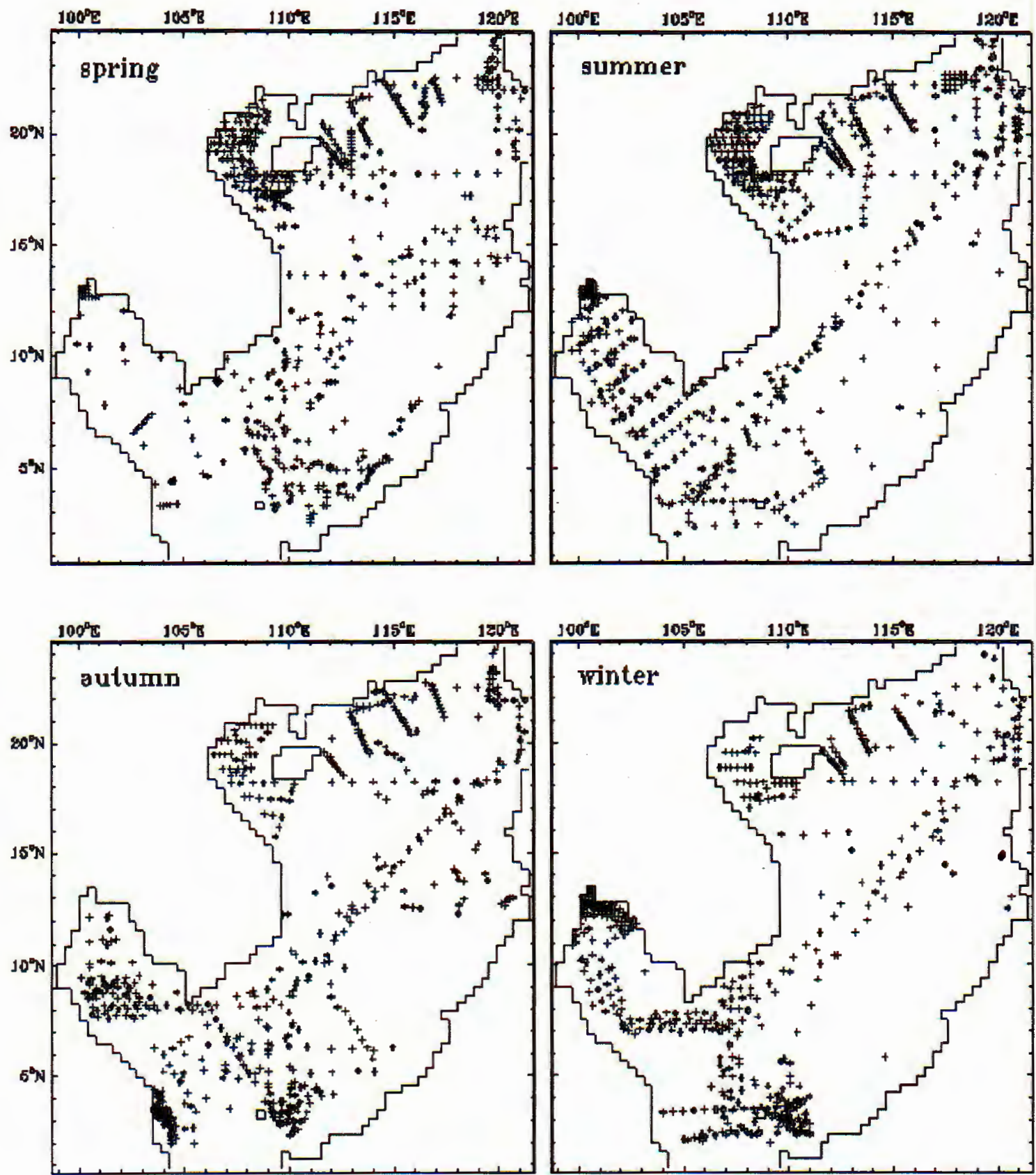

Fig. 3. Locations of seawater temperature and salinity observation

\section{Diagnostic numerical model}

Using conventional notation, the governing equations in Cartesian coordinates are as follows: 


$$
\begin{aligned}
& \frac{\partial u}{\partial x}+\frac{\partial v}{\partial y}+\frac{\partial w}{\partial z}=0 \\
& \frac{\partial u}{\partial t}+u \frac{\partial u}{\partial x}+v \frac{\partial u}{\partial y}+w \frac{\partial u}{\partial z}-f v=-\frac{1}{\rho} \frac{\partial p}{\partial x}+\frac{\partial}{\partial x}\left(A_{h} \frac{\partial u}{\partial x}\right)+\frac{\partial}{\partial y}\left(A_{h} \frac{\partial u}{\partial y}\right) \\
& +\frac{\partial}{\partial z}\left(A_{v} \frac{\partial u}{\partial z}\right)+F_{t x} \\
& \frac{\partial v}{\partial t}+u \frac{\partial v}{\partial x}+v \frac{\partial v}{\partial y}+w \frac{\partial v}{\partial z}+f u=-\frac{1}{\rho} \frac{\partial p}{\partial y}+\frac{\partial}{\partial x}\left(A_{h} \frac{\partial v}{\partial x}\right)+\frac{\partial}{\partial y}\left(A_{h} \frac{\partial v}{\partial y}\right) \\
& +\frac{\partial}{\partial z}\left(A_{v} \frac{\partial v}{\partial z}\right)+F_{t y} \\
& p=\rho_{0} g \zeta+\int_{z}^{\zeta} g \frac{\rho_{0}-\rho}{\rho_{0}} d z, \quad \rho=\rho(T, S) \\
& \frac{\partial T}{\partial t}+u \frac{\partial T}{\partial x}+v \frac{\partial T}{\partial y}+w \frac{\partial T}{\partial z}=\frac{\partial}{\partial x}\left(D_{h} \frac{\partial T}{\partial x}\right)+\frac{\partial}{\partial y}\left(D_{h} \frac{\partial T}{\partial y}\right) \\
& +\frac{\partial}{\partial z}\left(D_{v} \frac{\partial T}{\partial z}\right)+\gamma\left(T^{*}-T\right) \\
& \frac{\partial S}{\partial t}+u \frac{\partial S}{\partial x}+v \frac{\partial S}{\partial y}+w \frac{\partial S}{\partial z}=\frac{\partial}{\partial x}\left(D_{h} \frac{\partial S}{\partial x}\right)+\frac{\partial}{\partial y}\left(D_{h} \frac{\partial S}{\partial y}\right) \\
& +\frac{\partial}{\partial z}\left(D_{v} \frac{\partial S}{\partial z}\right)+\gamma\left(S^{*}-S\right) \text {. }
\end{aligned}
$$

Here $u, v, w$ are velocity components in $x, y, z$ directions respectively, $f$ the Coriolis parameter ( $=2 \omega \sin \varphi, \omega$ is the angular velocity of the earth's rotation, $\varphi$ is latitude), $g\left(=980 \mathrm{~cm} / \mathrm{s}^{2}\right)$ the acceleration due to gravity, $F_{t x}, F_{t y}$ tidal stresses, $t$-time, $p$-water pressure, $\rho$-water density, $\rho_{0}$-overall mean water density, $\zeta$-sea level height above the mean sea surface, $A_{h}, D_{h}$ horizontal eddy viscosity and diffusivity, respectively, $A_{v}$, $D_{v}$ vertical eddy viscosity and diffusivity, respectively, $T$-water temperature, and $S$-salinity. Horizontal tidal stress components $\left(F_{t x}, F_{t y}\right)$ are calculated by:

$$
F_{t x}=-\sum_{i=1}^{4} \overline{\left(\widetilde{u}_{i} \frac{\partial \widetilde{u}_{i}}{\partial x}+\widetilde{v}_{i} \frac{\partial \widetilde{u}_{i}}{\partial y}\right)}, \quad F_{t y_{i}}=-\sum_{i=1}^{4} \overline{\left(\widetilde{u}_{i} \frac{\partial \widetilde{v}_{i}}{\partial x}+\widetilde{v}_{i} \frac{\partial \widetilde{v}_{i}}{\partial y}\right)} .
$$

Here $\widetilde{u}_{i}$ and $\widetilde{v}_{i}$ denote the horizontal tidal current components of $M_{2(i=1)}, S_{2(i=2)}$, $K_{1(i=3)}$ or $O_{1(i=4)}$ tide, and the over bar represents the average over one tidal cycle for each component.

The last terms in equations (3.5) and (3.6) are called $\gamma$-terms which are introduced by Sarmiento and Bryan (1982) to prevent calculated values of $T$ and $S$ from deviating greatly from the observed ones $T^{*}$ and $S^{*}$. 
In addition, the following initial and boundary conditions are used: Initial conditions:

$$
u=v=w=0, \quad \zeta=0, \quad T=T^{*}, \quad S=S^{*} \quad \text { at } t=0 .
$$

At the sea surface:

$$
\rho A_{v} \frac{\partial u}{\partial z}=\rho_{a} C_{d}|W| W_{x}, \quad \rho A_{v} \frac{\partial v}{\partial z}=\rho_{a} C_{d}|W| W_{y}, \quad \frac{\partial T}{\partial z}=\frac{\partial S}{\partial z}=0 .
$$

At the bottom:

$$
\rho A_{v} \frac{\partial u}{\partial z}=\beta \sqrt{\left(u^{2}+v^{2}\right)} u, \quad \rho A_{v} \frac{\partial v}{\partial z}=\beta \sqrt{\left(u^{2}+v^{2}\right)} v .
$$

Along the lateral solid boundary:

$$
u=v=0, \quad \frac{\partial T}{\partial n}=\frac{\partial S}{\partial n}=0 .
$$

Along the lateral open boundary: $T$ and $S$ are given on the basis of observed values and volume transports are prefixed.

Here $\rho_{a}\left(=0.0012 \mathrm{~g} / \mathrm{cm}^{3}\right)$ is the air density, $C_{d}(=0.0013)$ the sea surface drag coefficient, $W$ the wind vector, $\beta(=0.0026)$ the bottom drag coefficient, $\vec{n}$ the unit outward vector.

The above mentioned equation system is solved by the finite difference method after a vertically $\sigma$-stretched transformation is applied (Sheng, 1987). In the $\sigma$ coordinate the complex topography is approximated more accurately. However, truncation errors associated with the horizontal pressure force become significant. Using the cubic spline interpolation mitigates this disadvantage (Ahlberg, 1967). More detailed information about the numerical model is given in Manh and Yanagi (1997). The grid size of the model is $40 \mathrm{~km}$ in the horizontal. Water column is divided into 32 layers with the thickness increasing with depth. Other parameters are taken as: $A_{h}=D_{h}=10^{7} \mathrm{~cm}^{2} / \mathrm{s}, A_{v}=150 \mathrm{~cm}^{2} / \mathrm{s}, D_{v}=50 \mathrm{~cm}^{2} / \mathrm{s}, \gamma=1 / 24$ hours and time step $\Delta t=120 \mathrm{~s}$.

\section{Obtained Results}

Residual flows in 4 seasons (spring, summer, autumn and winter) were calculated. In consistence with some previous numerical models (Pohlmann, 1987; Shaw, 1994), the quasi-steady states were obtained about 15 days after the beginning of the calculation. At the open boundaries the volume transport across the boundaries were given on the basis of the estimation from Wyrtki (1961) as shown in Table 1, where the positive and negative values indicate inflow and outflow, respectively. 

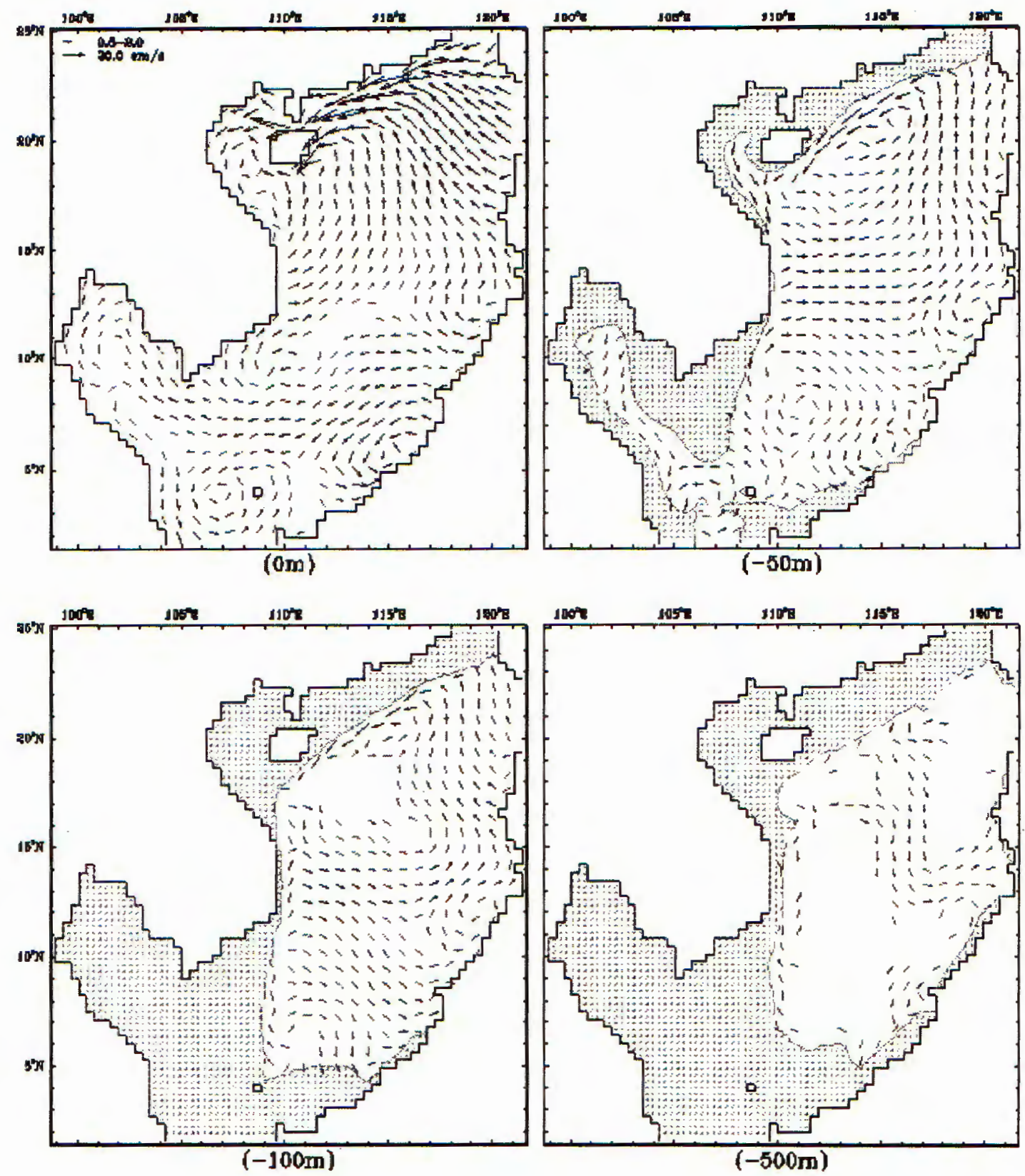

Fig. 4. Calculated residual flow in spring at four levels $(0,-50,-100$ and $-500 \mathrm{~m})$. Current vector below $0.5 \mathrm{~cm} / \mathrm{s}$ is not shown

Figure 4 presents the calculated residual flow in spring at 4 levels $(0,-50,-100$ and $-500 \mathrm{~m}$ ). The residual flow is relatively small, except in the Chinese coastal zone. In this region the flow direction is westward. At the $0 \mathrm{~m}$ level, in the Gulf of Tongking the residual flow circulates counterclockwise. In the southern part of the Vietnamese coastal zone the flow direction is northeastward, and a big clockwise 
eddy exists offshore. The flow direction is westward in the southern part of the ES and is northwestward in the gulf of Thailand. A counterclockwise eddy exists in the southern part of the Sunda Shelf. At the middle levels $(-50 \mathrm{~m}$ and $-100 \mathrm{~m})$, the residual flow circulates counterclockwise in the northern part of the ES, but clockwise in the southern part.
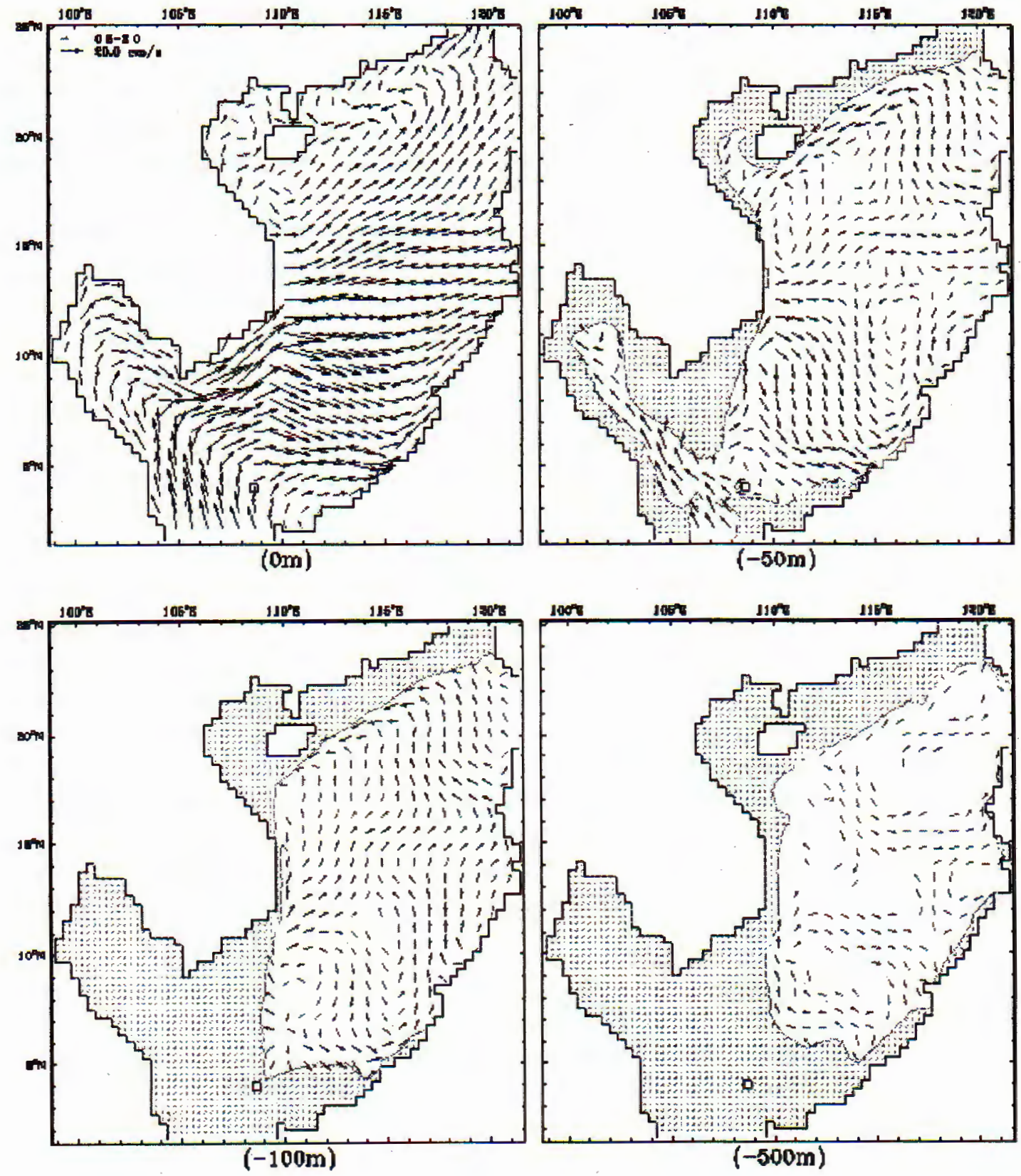

Fig. 5. Calculated residual flow in summer at four levels $(0,-50,-100$ and $-500 \mathrm{~m})$ In summer, the residual flow is relatively strong in comparison with that in 
spring as shown in Fig. 5. At the $0 \mathrm{~m}$ level, the flow in the central and southern parts of the ES is the strongest with eastward direction. In the gulf of Thailand, the residual flow circulates clockwise. In the northern part of the ES, the flow is smaller and has northeastern direction. At the middle levels $(-50 \mathrm{~m}$ and $-100 \mathrm{~m})$, the flow is westward in the northern shelf zone and there is a counterclockwise circulation in the northern part of the ES. In the southern part of the ES, there is a clockwise eddy off the Vietnamese coast, and another counterclockwise off the north of Kalimantan. The flow direction in the coastal zones of Kalimantan and Luzon Islands is northward. In the southern part of the Vietnamese coastal zone, the flow runs seaward. At the lower level $(-500 \mathrm{~m})$, the residual flow is small and, generally, circulates counterclockwise in the northern part and clockwise in the southern part of the ES.

Simulation of the residual flow in autumn is presented in Fig. 6 . At the $0 \mathrm{~m}$ level, in the northern part of the ES, generally, the residual flow pattern is similar as that in spring, except the location of the counterclockwise eddy moves southwestward. In the central part of the ES, a counterclockwise eddy occurs in the middle part of the Vietnamese coastal zone. The flow in the Gulf of Thailand is small and circulates clockwise, and in the southern part of the ES the flow direction is mainly westward. At the middle levels $(-50 \mathrm{~m}$ and $-100 \mathrm{~m})$, in the northern and central parts of the ES the residual flow direction is mainly northeastward, and a counterclockwise gyre exists off the mouth of the Gulf of Tongking. At the lower level $(-500 \mathrm{~m})$ the flow tendency is in counterclockwise circulation.

In winter, the residual flow is the strongest, as shown in Fig. 7. At the $0 \mathrm{~m}$ level, the flow direction, in general, is westward while in the Gulf of Tongking and the Gulf of Thailand the flows circulate counterclockwise. It means that the residual flow patterns at the $0 \mathrm{~m}$ level in winter and in summer are almost opposite. At the $-50 \mathrm{~m}$ levels, the flow direction is mainly northeastward, except in the shelf areas. In the coastal zone of China and the Middle of Vietnam the flow direction is southwestward and southward, respectively. In other words, there is a counterclockwise circulation off Hainan Island. At the $-100 \mathrm{~m}$ level, the flow direction in the northern part of the ES is mainly southwestward, while in the southern part it is eastward. There is a big counterclockwise gyre in the central part of the ES at the lower level $(-500 \mathrm{~m})$.

Table 1. Bimonthly transports (in $10^{6} \mathrm{~m}^{3} / \mathrm{s}$ ) across the open boundaries, see Fig. 1. Positive value indicates inflow and vice versa

\begin{tabular}{|c|c|c|c|c|}
\hline & Spring & Summer & autumn & Winter \\
\hline Taiwan Strait & 0.03 & -0.7 & 0.5 & 0.5 \\
\hline Bashi Channel & 0.04 & -2.5 & 0.5 & 2.8 \\
\hline Karimata Strait & -0.07 & 3.2 & -1.0 & -3.3 \\
\hline
\end{tabular}



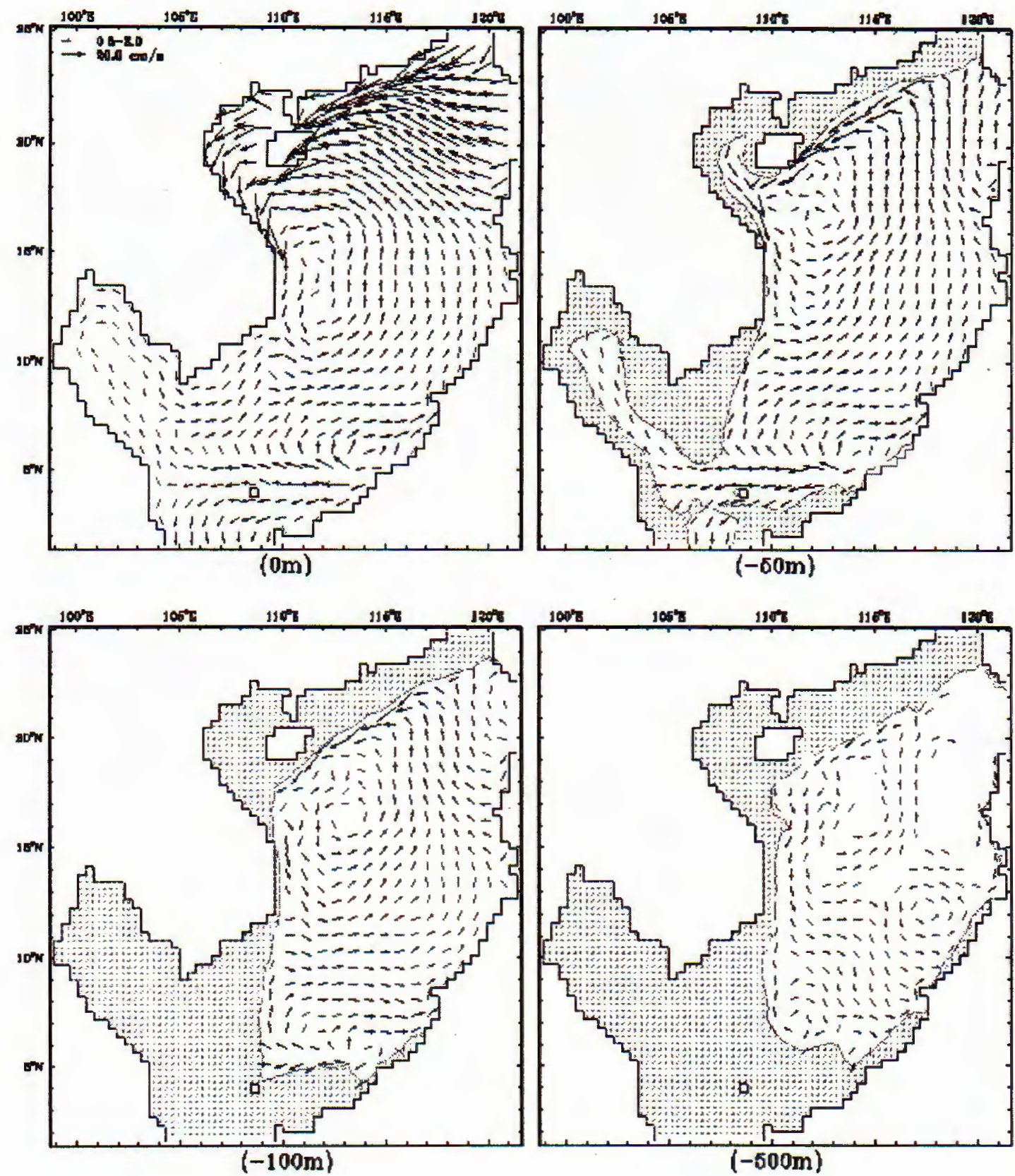

Fig. 6. Calculated residual flow in autumn at four levels $(0,-50,-100$ and $-500 \mathrm{~m})$

Figure 8 draws the surface currents derived from ship drift in August and December (Levitus, 1982). It shows that the calculated residual flows at the surface in summer and winter agree with these observations. 

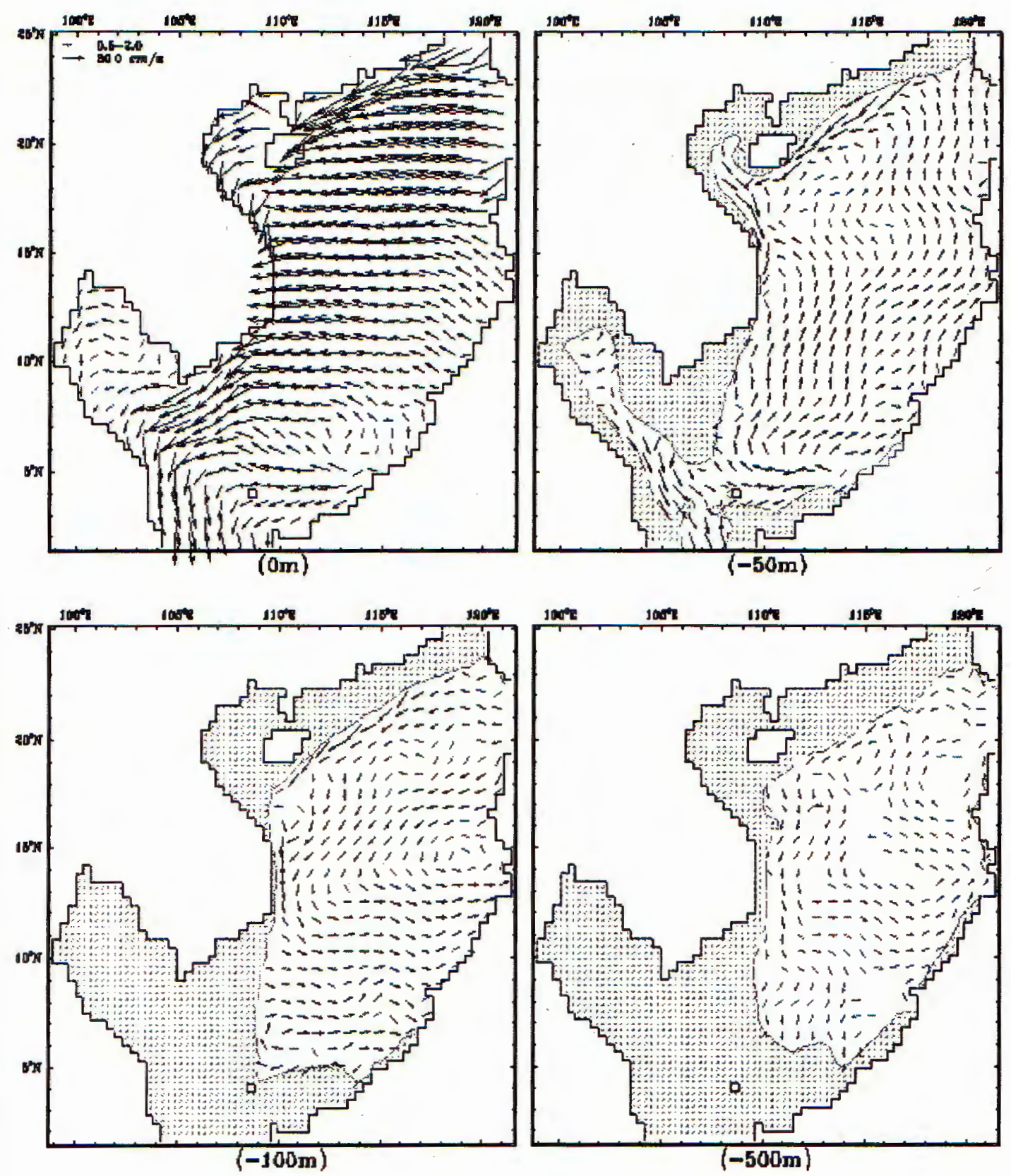

Fig. 7. Calculated residual flow in winter at four levels $(0,-50,-100$ and $-500 \mathrm{~m})$

\section{Discussion and Remarks}

In this study we have applied a constant vertical eddy viscosity to enclose the equation system and a large $\gamma$-term (robust diagnostic model). In fact, a number of values of $A_{v}$ were taken to simulate the residual flow in summer and the calculated 
results were compared qualitatively with observed ones in Fig. 8a. Finally, one of the above values of $A_{v}$ was chosen (calibrating) and then applied for simulation of residual flow in winter. The obtained results were acceptable in comparison with observation, shown in Fig. $8 \mathrm{~b}$ (validating). It is obvious that the sea water temperature and salinity fields, averaged from the observed data, may be, are not satisfying the equation of mass conservation, therefore, the $\gamma$-term is included in order to produce calculated water temperature and salinity fields that are closed to the observed data and satisfying the equation of mass conservation. Furthermore,
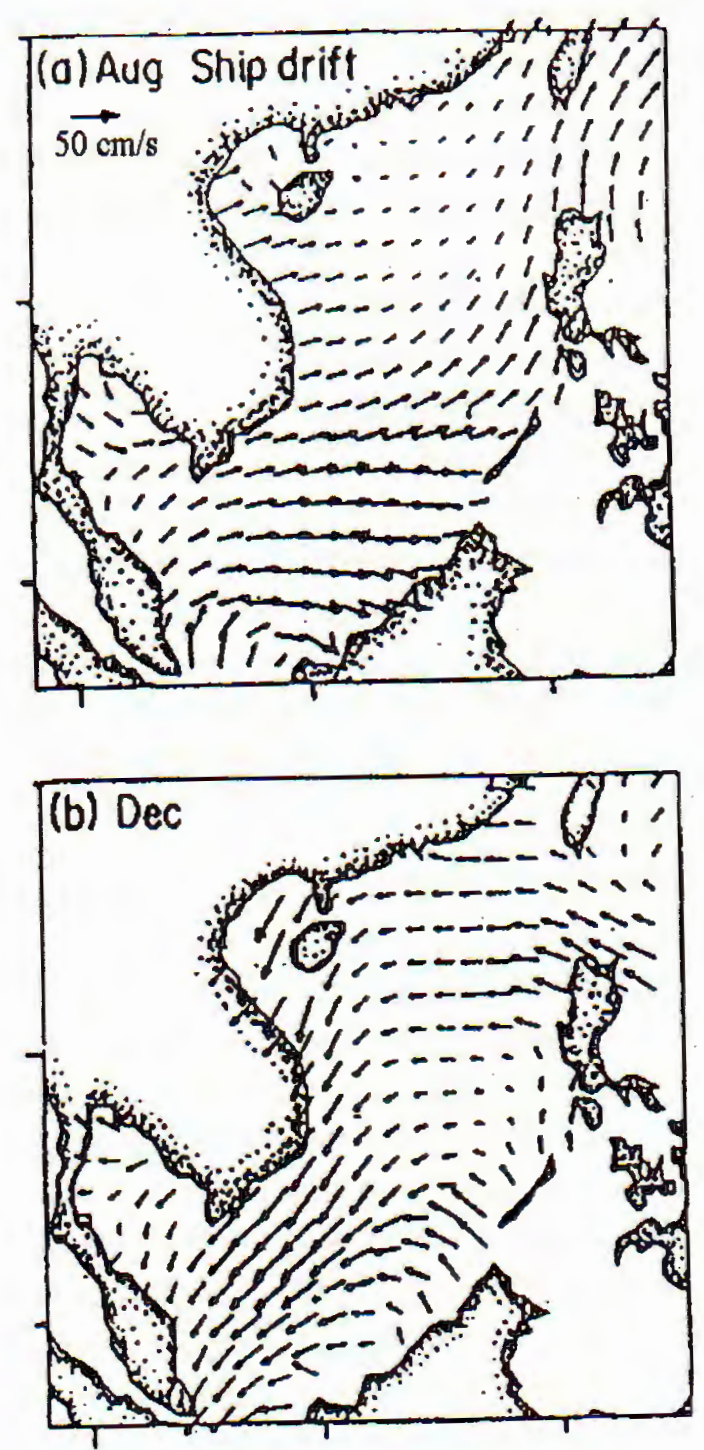

Fig. 8. Surface velocity derived from ship drift (Levitus, 1982) in (a) August and (b) December (after Shaw et al, 1994) 
the $\gamma$-term works as a correction factor when heating/ cooling at the sea surface are not taken into consideration in the model.

In the Pohlmann model, the boundary conditions required vanishing normal derivatives of the normal velocity components on the open boundaries. The obtained results from Shaw et al model did not show any contribution of density-driven current in deep layers. This, may be, due to using the climatological temperature and salinity distributions from Levitus, 1982, that were strong smooth from the observed data. Simulations obtained from Uu et al model showed the current pattern at the sea surface to be quite different in comparison with the Levitus map, and in summer as well as in winter, a spuriously strong clockwise eddy exists near the Bashi Channel. Instead of these, in this numerical model, the newer data set of sea water temperature and salinity were used, as well as the water mass exchanged through the open boundaries were evaluated and included. Furthermore, the finer grid sizes, especially in the vertical direction were applied. Therefore, the above-mentioned week-points were removed.

In order to evaluate the contribution of each component (wind-driven, densitydriven and tide-induced residual) of the residual flow as well as the influence of the adjacent sea on the residual flow pattern in the ES, some more numerical experiments were carried out: (1) Wind-driven currents in summer and in winter and tideinduced residual currents were calculated separately with the uniform density fields ( $\rho=\rho_{0}$ for each season) and using a modified form of Sommerfeld radiation condition (Blumberg et al, 1985) at the open boundaries. (2) It was supposed that there were no in-out flows at the open boundaries while all other conditions remained unchanged, the wind-driven currents and currents of all components in winter were calculated. The above-mentioned radiation condition is described as follows:

$$
\zeta_{t}+(g H)^{1 / 2} \zeta_{n}=-\zeta / T_{f} \text {, where } H \text { is water column, } T_{f} \text { (=1 hour) the time factor. }
$$

The calculated wind-driven currents in both two numerical experiments show that the residual flow pattern at the surface layer is mainly driven by wind-driven current. At the $-100 \mathrm{~m}$ and lower levels the speed of the wind-driven currents is small and a small difference exists between summer and winter. The tide-induced residual flow is relatively small. Generally, its speed is less than several centimeters per second. It is clear that regions with a considerable tide-induced flow are shallow water regions.

As a result, during winter, under the strong $\mathrm{NE}$ wind, the residual flow is the strongest and generally the flow direction is from east to west in the surface layer, while during summer, the flow speed is weaker and its direction is almost reversed due to the weaker SW wind. During spring and autumn, the residual flows are quite small in comparison to those in winter and summer, except in the northern part of the ES where the NE winds blow.

In the second numerical experiment (without in-out flows), it is shown that the pattern of the residual flow in the ES is weakly influenced by the in-out flows. The 
calculated residual flow pattern at the $0 \mathrm{~m}$ level in this case is quite similar to the result of the original case, except on the shelf area of Karimantan where a large counterclockwise gyre exists due to closed boundary effect. At the $-100 \mathrm{~m}$ level the obtained result is almost unchanged in comparison with that of the original case. This may be explained by the relatively small amount of water exchange between the ES and the surrounding seas through the shallow straits.

The contribution of the density-driven component is evaluated by comparing the calculated residual currents (Fig. 5 and 6) and the calculated wind-driven currents (not presented here) during summer and winter. The patterns of the residual currents in the lower levels $(-50,-100$ and $-500 \mathrm{~m})$ are quite different with those of the wind-driven currents, except at the $-50 \mathrm{~m}$ level during winter. It means the residual flow patterns at the lower levels are driven by the density distributions. The more evident influence of the wind-driven current on the residual flow pattern at the $-50 \mathrm{~m}$ level during winter can be explained by the stronger wind field in this season.

The existence of rather strong currents in the southern part of the sea near to the Vietnam coast have also been reported in literatures. For example, the numerical simulation of Pohlmann (1987) suggests the existence of a southward current in winter and a northward current in summer off south of Vietnam. Shaw and Chao (1994) present similar currents.

It is noted that a heavier water zone exists in the northern part of the ES. This zone, varying from season to season, is formed by the higher saline water that comes from the Pacific Ocean through the Bashi Channel, especially during winter. The calculated residual current in winter (Fig. 7) shows that there is a northwestward flow at the $-100 \mathrm{~m}$ level from the Bashi Channel. Due to the existence of the heavier water mass, throughout the year the residual currents at the $-50 \mathrm{~m}$ level in the central part of the ES, between the Luzon Island and the middle part of the Vietnamese coast, are in tendency to flow northeastwards. In the coastal zone of China the current direction is northwestward and in the central part of the Vietnamese coast it is northward. This does agree with the recent observations, carried out by the Center for Marine Environment Survey, Research and Consultation of Vietnam (private communication), along the Vietnamese coastal zone.

\section{Conclusions}

On the basis of the calculated results of the residual flow in the ES the following conclusions are obtained:

- At the surface layer, the residual flow pattern is mainly driven by the winddriven current. During winter, the residual flow is the strongest and generally the flow direction is from east to west, while during summer, the flow speed is smaller and its direction is almost reversed. During spring and autumn, the residual flows are quite small in comparison to those in winter and summer.

- At the lower levels, the flow patterns are mainly driven by the density distribution. 
- Throughout the year the residual currents at the lower levels in the central part of the ES, between the Luzon Island and the middle part of the Vietnamese coast, are in tendency to flow northeastwards. The current direction is northwestward in the coastal zone of China and northward in the central part of the Vietnamese coast.

- The tide-induced residual flow is relatively small.

This study is supported partly by the Basic Research Project "Hydrodynamics and Marine environment", code: 32 .

\section{REFERENCES}

1. Ahlberg J. H., Nilson E. N. and Walsh J. L. (1967). The theory of splines and their application. New York Academic Press.

2. Blumberg A. F. and Kantha L. H. (1985): Open boundary condition for circulation models, J. of Hydraulic Engineering, Vol. 111, No. 2, 237-255.

3. Cressie N. A. C. (1991). Statistics for spatial data, John Wiley and Sons, Inc., New York, $900 \mathrm{pp}$.

4. Levitus S. (1982): Climatological atlas of the world ocean, NOAA Professional Paper No. 13, U.S. Government Printing Office, Washington, DC, 173 pp.

5. Manh D. V. and Yanagi T. (1997). A three-dimensional numerical model of tides and tidal currents in the Gulf of Tongking. La mer, 35, pp. 5-22.

6. Pohlmann T. (1987). A three-dimensional circulation model of the South China Sea. In: Three-dimensional models of marine and estuarine dynamics, J. J. Nihoul and B. M. Jamart, editors, Elsevier, New York, pp. 245-268.

7. Sarmiento J. L. and Bryan K. (1982). An ocean transport model for the North Atlantic. J. Geophys. Res., 87, 394-408.

8. Shaw P. T. and Chao S. Y. (1994). Surface circulation in the South China Sea. Deep-Sea Research, Vol. 41, No. 11/12, pp. 1663-1683.

9. Sheng Y. P. (1987). On modeling three-dimensional estuarine and marine hydrodynamics. In: Three-dimensional models of marine and estuarine dynamics, J. J. Nihoul and B. M. Jamart, editors, Elsevier, New York, pp. 35-54.

10. Uu D. V. et al (2001). A three-dimensional model of circulation and thermo-saline structures in the East Sea. Special subject report of State Project KHCN-06-02, 160pp (in Vietnamese).

11. Wyrtki K. (1961). Physical oceanography of the Southeast Asian water. NAGA Report Vol.2, Scientific Results of Marine Investigations of the South China Sea and the Gulf of Thailand, Scripps Institution of Oceanography, La Jolla, California, 195 pp. 


\section{SỰ THAY ĐỔI MÙA CỦA DÒNG DU Ở BIỂN ĐÔNG}

Trong bài này, mô hình số 3 chiều dã được thiết lập để xem xét sự biến đổi theo mùa của dòng cháy dư, bao gồm dòng do gió, dòng mật độ và dòng triều lưu dư trong vùng biển Đông. Các số liệu quan trắc về nhiệt độ và độ mặn nước biển được khai thác từ Trung tâm Dữ liệu Hải dương Nhật Bản (JODC) trong giai doạn 1930 -1996 , và số liệu gió trung bình tháng từ Ưy ban Khí quyển Đại dương quốc gia Mỹ (NOAA), 1961-1991. Đã mô phơng dòng cháy dư trong 4 mùa (xuân, hạ, thu và đông) và đánh giá vai trò của từng thành phần dòng chảy. Cằc kết quả nhận được cho thấy dòng cháy gió có vai trò quan trọng nhất trong việc tạo nên hoàn lưu chung của biển Đông, đặc biệt là tầng mặt. Ở các tầng sâu hơn, dòng chảy mật độ trớ nên quan trọng hơn. Dòng triều lưu dư trong biển Đông tương dối nhỏ.

\section{MộT SỐ NÉT VỀ CUộC THI OLYMPIC CƠ HỌC TOÀN QUỐC LẦN THỨ XV - 2003}

Cơ quan chủ trì: Hội Co học Việt Nam - Bộ Giáo dục và Đào tạo - Hội Sinh viên Việt Nam.

Ngày thi: 11/5/2003 (Đồng thời tại 3 địa điểm)

Trường dăng cai: - Đại học Kiến trúc Hà Nội

- Đại học Kỹ thuật Đà Nẳng - Đại học Đà Nẵng

- Đại học Nông lâm Tp. Hồ Chí Minh.

Môn thi: Cơ lý thuyết, Sức bền vật liệu, Co học kết cấu, Thủy lực, Cơ học đất, Nguyên lý máy, Chi tiết máy.

\section{Trường ban tổ chức: GS TSKH Vũ Duy Quang}

Ban giám khảo 7 môn: 179 GS, PGS, TSKH, TS, ThS.

Số trường tham gia: 23 trong đó 13 trường phía Bắc, 9 trường phía Nam và 1 trường ở Đà Nẵng (tăng 4 trường so với năm ngoái)

Tổng số thí sinh dự thi: 783 (tăng 93 thí sinh so với năm ngoái)

Tổng số giải thường:

\begin{tabular}{cccccccc}
\multicolumn{3}{c}{ Cá nhân } & \multicolumn{3}{c}{ Đồng đội } \\
\cline { 1 - 3 }$\frac{\mathrm{I}}{13}$ & $\frac{\mathrm{II}}{30}$ & $\frac{\mathrm{III}}{58}$ & $\frac{\mathrm{KK}}{104}$ & & $\frac{1}{7}$ & $\frac{\mathrm{II}}{7}$ & $\frac{\mathrm{III}}{7}$ \\
\hline
\end{tabular}

Chiếm tý lệ: $29 \%$

Ban tổ chức xin chân thành cám ơ 22 cơ quan, trường Đại học, Tổng Công ty, Các hội cơ học chuyên ngành đã tài trợ cho tổ chức cuộc thi Olympoc Cơ học.

Ngày tổng kết trao giải thường: 14/6/2003 Tại trường Đại học Kiến trúc Hà Nội. 